(2) Short-term relief of obstruction in a patient who is awaiting pyeloplasty, when there is a risk that pyonephrosis may developfor example, after retrograde catheterization. We would also suggest that it might be of value to produce preliminary decompression of the renal pelvis and allow contraction of the stretched tissues, making subsequent surgery easier.

(3) Assessment of potential recovery of an obstructed kidney or in a non-functioning moiety of an obstructed duplex kidney.

For the most part these indications require little comment. Cases with suspected malignant disease involving both ureters raise difficult problems of management, since the benefit resulting from relief of obstruction is likely to be temporary and it may at times be more humane not to allow the patient to recover sufficiently from renal failure to experience the direct effects of the growth. But in other cases of anuria due to obstruction there is every advantage in improving the general condition of the patient and diminishing the risk of infection before curative surgery. In unilateral obstructive disease there is an interesting further possibility, since a period of satisfactory drainage makes it possible to assess the likely return of function with adequate relief of obstruction (see our Case 7 and Goodwin et al. (1955) Case 2). This, in our view, offers a most promising area for further extension of the method. The importance of conserving renal tissue is undoubted, yet after a period of chronic obstruction it may be impossible to predict whether adequate function can be restored to a kidney even if the obstruction is satisfactorily relieved. Percutaneous nephrostomy offers a practical way of resolving such uncertainties.
The particular technique recommended is not definitive. For the purpose of simple drainage the No. 5 ureteric catheter is adequate, but narrower catheters could be preferable for other purposes-for example, long-term manometric studies and the instillation of antibiotics, chemotherapeutic agents, or stone-dissolving fluids. At times a wider catheter might be needed. Whatever the future extensions of the method, the existing technique is, in our view, a significant advance in the management of obstructive disease of the upper urinary tract.

We would like to thank the physicians and surgeons who referred these patients to us, and Mr. F. R. Kilpatrick and Mr. C. H. Kinder for their advice and help.

\section{REFERENCES}

Bosniak, M. A., Scheff, S., and Kaufman, S. (1968). Fournal of Urology, 99, 241.

Casey, W. C., and Goodwin, W. E. (1955). Fournal of Urology, 74, 164. Cobb, B. (1967). Fournal of Urology, 98, 309.

Floyd, E., and Guy, J. C. (1956). Fournal of the Medical Association of Georgia, 45, 13.

Goodwin, W. E., Casey, W. C., and Woolf, W. (1955). Fournal of the American Medical Association, 157, 891.

Lalli, A. F. (1968). Radiology, 90, 331.

Lundin, E., and Wadström, L. B. (1965). Acta Chirurgica Scandinavica. $130,267$.

Maldonado, J. (1966). Fournal of Urology, 96, 651.

Weens, H. S., and Florence, T. J. (1954). Fournal of Urology, 12, 589.

Wickbom, I. (1954). Acta Radiologica, 41, 505.

\title{
Latent Cytomegalovirus Infection in Blood Donors
}

\author{
PETER DIOSI,* M.D.; EVA MOLDOVAN,* M.D.; NICHOLAS TOMESCU, $†$ M.D.
}

\begin{abstract}
Summary : Twenty-one out of 32 apparently healthy blood donors aged 21 to 65 years yielded positive complement fixation tests with a cytomegalovirus antigen, at titres ranging from $1: 8$ to $1: 64$. Virus was present in leucocyte cultures of fresh peripheral blood of two seropositive subjects from a total of 35 donors examined. Plasma and 48-hour stored blood specimens failed to disclose virus in culture. Viruria could not be demonstrated, and there was no evidence of recent illness in the study group. These findings suggest that subclinical viraemia is not uncommon in blood donors.
\end{abstract}

\section{Introduction}

Wyatt et al. (1951) were the first to assume that cytomegalovirus infection could be the result of the introduction of virus into a non-carrier by transfusion with blood from a carrier. Since then the occurrence of cytomegaloviraemia has been hown by the recovery of cytomegalovirus strains from the buffy-coat layer of a blood sample received from a patient with giant-cell type hepatitis (Stulberg et al., 1966), as well as from washed leucocytes obtained from the peripheral blood in cases of congenital cytomegalic inclusion disease (Demidova et al., 1968), post-transfusion mononucleosis (Foster and Jack, 1968),

* Institute of Hygiene, Timisoara, Rumania. + Centre of Blood Transfusions, Timisoara, Rumania. post-perfusion syndrome (Lang et al., 1968), lymphatic leukaemia (Harnden et al., 1967 ; Diosi and Roth, 1969), and myeloid leukaemia (Jack et al., 1968).

Since generalized cytomegalic inclusion disease and cytomegalovirus mononucleosis have been shown to develop after the transfusion of fresh blood (Kääriäinen et al., 1966a; Henson, 1967.), in connexion with renal haemodialysis (Cutforth et al., 1968), or surgery with extracorporeal circulation (Anderson and Larsson, 1963 ; Embil et al., 1968 ; Marton et al., 1968 ; Foster and Jack, 1969), attempts were made in the present study to recover cytomegalovirus from donated fresh blood and from blood specimens stored for 48 hours before their administration.

\section{Materials and Methods}

The study group, which came from the Blood Transfusion Centre in Timişoara, consisted of 35 blood donors aged 21 to 65 years, belonging at random to various blood groups. Routine haemograms and urine analyses yielded normal values in each case, while serology for syphilis and hepatocellular function tests were negative. None of the individuals surveyed showed any sign of disease.

\section{Virological Techniques}

Details of the laboratory methods employed have for the most part been reported elsewhere (Diosi and Roth, 1969). 
Suspension cultures of leucocytes were prepared at one hour and after 48 hours' preservation at $4^{\circ} \mathrm{C}$. by gravity sedimentation of heparinized peripheral blood, followed by low-speed centrifugation of the plasma supernatant rich in leucocytes. Thereafter plasma and leucocytes were handled separately. Plasma was inoculated in $0 \cdot 2-\mathrm{ml}$. amounts on to tube cultures of human embryo fibroblasts, while the cell button was repeatedly washed and finally diluted with cell culture medium containing $5 \%$ agammaglobulinaemic calf serum to yield about 1,000 cells per cu. mm. Aliquots of $1.5 \mathrm{ml}$. of this suspension were distributed in tubes and cultured at $37^{\circ} \mathrm{C}$. for 72 hours. Then the medium was removed and the sedimented cells were resuspended to their original volume in gelatin saline. In parallel, cells were sampled by cytological examination.

After another centrifugation the pellet was redispersed in $1.5 \mathrm{ml}$. gelatin saline and inoculated uncounted on to tube cultures of human embryo fibroblasts maintained in a medium comprising $2.5 \%$ calf serum, $20 \%$ lactalbumin hydrolysate, $2.5 \% \mathrm{~N} 16$ solution, and $75 \%$ Earle's solution supplemented with penicillin and streptomycin. All the cultures were incubated at $35^{\circ} \mathrm{C}$., medium being changed and the cell sheet examined twice a week for a period of six weeks before being discarded as negative. Isolates were presumptively identified by the appearance of the cytopathic effect characteristic of cytomegalovirus and by human fibroblastic cell culture specificity.

One-millilitre specimens of freshly voided urine were used without preliminary manipulations in attempts to recover the virus by inoculation on to human embryo fibroblast cultures.

\section{Cytological Studies}

Search for exfoliated inclusion-bearing cells was accomplished on smears of urine sediment fixed in a mixture of equal parts of ether and $96 \%$ ethyl alcohol, stained with haematoxylin and eosin and mounted under a coverslip in Canada balsam.

\section{Complement Fixation Tests}

The serum samples were screened for complement-fixing antibody to cytomegalovirus by the technique described by Halonen et al. (1958), with the use of an antigen prepared in our laboratory from an autochthonous cytomegalovirus strain in its 12th cell culture passage. All the tests were run concomitantly, including known positive and negative control sera. Fixation of complement at serum dilutions of $1: 8$ or more were interpreted as seropositive.

\section{Results}

Results of the serological survey, virus isolations, and cytological studies are recorded in the Table. Serological studies employing the complement fixation test showed positive titres of serum antibodies to cytomegalovirus in 21 out of 32 examined blood donors (about $65 \%$ ). Virus was recovered from inocula of washed leucocytes obtained from donated fresh blood from 2 out of 35 donors, whereas plasma and 48-hour

Exfoliative Cytology and Recovery of Virus from Healthy Blood Donors in Relation to Cytomegalovirus Complement-fixing Antibody Titres

\begin{tabular}{|c|c|c|c|c|c|}
\hline \multirow{2}{*}{\multicolumn{2}{|c|}{ Titres }} & \multirow{2}{*}{$\begin{array}{l}\text { No. of } \\
\text { C.F. Tests }\end{array}$} & \multicolumn{2}{|c|}{ Recovery of Virus from } & \multirow{2}{*}{$\begin{array}{l}\text { Cytomegalic } \\
\text { Cells in Urine } \\
\text { Sediment }\end{array}$} \\
\hline & & & Blood & Urine & \\
\hline $\begin{array}{l}\text { Negative } \\
1: 8 \\
1: 16 \quad \ldots \\
1: 32 \quad \ldots \\
1: 64 \\
1: 128 \\
\text { Not tested }\end{array}$ & $\begin{array}{l}. \\
\ldots \\
\because \\
\ldots \\
\ldots\end{array}$ & $\begin{array}{r}11 \\
3 \\
6 \\
10 \\
2 \\
0 \\
3\end{array}$ & $\begin{array}{l}0 \\
0 \\
1 \\
1 \\
0 \\
0 \\
0\end{array}$ & $\begin{array}{l}0 \\
0 \\
0 \\
0 \\
0 \\
0 \\
0\end{array}$ & $\begin{array}{l}0 \\
0 \\
0 \\
0 \\
0 \\
0 \\
0\end{array}$ \\
\hline
\end{tabular}

stored blood specimens failed to disclose virus in culture. Positive cultures were incubated three to six weeks befare the cytopathic effect became evident, with no more than two or threew foci in each tube.

The two viraemic donors-a 21-year-old man belonging to group $\mathrm{A}_{2}$ and a 38-year-old group $\mathrm{O}$ woman-were seropositive. . but had no evidence of recent illness, and neither virus nor inclusion-bearing cells could be found in their urine. Leuco-o cytes cultured in suspension for 72 hours at $37^{\circ}$ C. showed no cytopathic changes characteristic of cytomegalovirus.

\section{Discussion}

Besides the increasing incidence of cytomegalic inclusion disease a new clinical syndrome attributed to cytomegalovirus (Kääriäinen et al., 1966a) has also arisen as a complication of operations requiring large transfusions of fresh blood (Kree?. et al., 1960) or extracorporeal circulation (Battle and Hewlett 1958), indicating that cytomegalovirus is far more than a harmless passenger in the blood stream.

A persistent infection of cultures established from peripherab blood of healthy donors due to a herpes type agent (Moore et al., 1967) and association of the latter with infectious mononucleosis (Niederman et al., 1968) and the post-perfusion syn-w drome (Gerber et al., 1969) have recently been reported. Nevertheless, it has been shown that this virus is identical with those found in cell lines derived from patients with Burkitt's lymphoma or leukaemia and is not a cytomegalovirus (Epstein and Achong, 1967 ; Henle and Henle, 1967).

Our findings show that cytomegalovirus is present in the blood of normal persons in an unexpectedly high proportion (about $5 \%$ ) and confirm indirect evidence accumulated about contamination of fresh blood recipients (Horton, 1966 Murphy et al., 1967 ; Langenhuysen and Kapsenberg, 1968)⿳亠丷厂 Repeated examinations and improvement of the virologicaf methods employed would probably raise this percentage evem more.

We suggest, however, that other factors could limit the importance of this artificial route of infection: fresh blood transfusions are not used frequently, viraemia resulting in healthy donors from asymptomatic activation of a latent infec-\$ tion is likely to be intermittent, and blood recipients with sero-s logical evidence of previous infection may be resistant when re-exposed to the same type of virus. At all events, the latter points still need elucidation.

Virus could not be detected in plasma specimens, as mighe be expected from the fact that the viraemic donors had cyto- 0 megalovirus antibodies in their sera. The cell-bound virus can however, spread directly from cell to cell without coming in contact with the extracellular environment containing the antio bodies.

Apart from transfusions, cytomegalovirus enters the bloof stream within infected cells released from the reticuloendotheliats and haemopoietic systems (Zuelzer et al., 1966 ; Bmbil et al.: 1968). The high incidence of subclinical cellular viraemia ife the blood-donor population may be attributed to the reactive proliferation of reticuloendothelial and haemopoietic tissues in these subjects, which is known to enhance the multiplication of the virus (Vogel, 1958).

Cytomegaloviruses are known to confer an increased surviva $\frac{\mathbb{P}}{8}$ on human cells transplanted to a heterologous host (Kisslinge and Addison, 1964), and prolonged survival of cytomegalo virus-infected leucocytes in long-term cultures has also been observed (Diosi, unpublished). This does not prove onco응 genicity of the virus, but may increase the efficiency of con-7은 tamination by transfusion.

The occurrence of cytomegalic inclusions in circulating leucocytes (Jarousse et al., 1956) has not been confirmed, and 
we were unable to detect such inclusions in cultured leucocytes. Possibly, however, cytomegalovirus may replicate within cells without production of the classical inclusion bodies (Zuelzer et al., 1966), and the occurrence of chromosome breaks in cultured lymphocytes derived from patients with cytomegalic inclusion disease (Krech and Jung, 1968) suggests that the virus can be transmitted to these cells and that it induces chromosomal lesions. The recovery of virus from washed leucocytes shows that release of mature virus also takes place in the absence of characteristic cytopathic changes.

Cytomegalovirus infection appears to develop in blood recipients with two main clinical manifestations-an interstitial pneumonitis designated as cytomegalic inclusion or cytomegalovirus pneumonia, and an infectious mononucleosis-like syndrome, with fever, splenomegaly, and atypical lymphocytes, described under various terms as cytomegalovirus mononucleosis (Kääriäinen et al., 1966b), post-perfusion syndrome (Reyman, 1966), etc. It is not clear as yet which factors determine the clinical course of the disease. Type differences between the virus strains involved might be a partial explanation.

Infectious mononucleosis is thought by some observers to represent an atypical form of acute leukaemia, with a selflimiting course (Dameshek and Gunz, 1964). It has to be remembered here that cytomegalovirus has been recognized as one of the aetiological agents of the infectious mononucleosis syndrome (Klemola and Kääriäinen, 1965 ; Kääriäinen et al., 1966b ; Anderson and Stern, 1966 ; Lamb and Stern, 1966 ; Toghill et al., 1967 ; Goor et al., 1968), silent infections caused by this agent being also described in association with leukaemia (Harnden et al., 1967).

Latent viral infections are thought to be essentially noncytopathic, and transmission of their causative agents to other hosts is achieved only with great difficulty. Cytomegaloviruses, though usually destructive agents readily transmitted to homologous hosts, appear, however, able to cause latent noncytopathic infection in susceptible cell systems.

As cellular viraemia with cytomegalovirus has important practical implications, we suggest that seronegative donors may be preferable for fresh blood transfusions until we know more about these problems.

We would like to thank Professor V. T. Busilă for his helpful suggestions. We are also indebted to Mrs. Valeria Virág, Mrs. Camelia David, and Miss Elisabeth Kecskés for their technical essistance.

Requests for reprints should be addressed to Dr. P. Diosi, Institute of Hygiene, Timişoara 5, Blv. Babeş 16, Rumania.
REFBRENCES

Anderson, J. P., and Stern, H. (1966). British Medical fournal, 1, 672. Anderson, R., and Larsson, O. (1963), Lancet, 2, 947.

Battle, J. D., jun., and Hewlett, J. S. (1958). Cleveland Clinic Quarterly, 25,112 .

Cutforth, R., Mitchell, R. M., and Mundy, G. R. (1968). Medical

Fournal of Australia, 2, 1103. p. 403. New York, Grune and Stratton.

Demidova, S. A., Gavrilov, V. I., Blyumkin, V. N., Semenova, E. I., and Zhdanov, V. M. (1968). Voprosy Virusologî, 13, 217.

Diosi, P., and Roth, L. (1969). Pathologia et Microbiologia, 33, 146.

Embil, j. A., Folkins, D. F., Haldane, E. V., and van Rooyen, C. E. (1968). Lancet, 2, 1151.

Epstein, M. A., and Achong, B. G. (1967). Cancer Research, 27, 2489.

Epstein, M. A., and Achong, B. G. (1967). Cancer Research, 27, 2489.

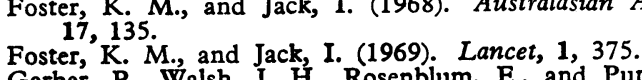

Gerber, P., Walsh, J. H., Rosenblum, E., and Purcell, R. H. (1969). Lancet, 1, 593.

Goor, W., Siegenthaler, P.; and Krech, U. (1968). Schweizerische Medizinische Wochenschrift, 98, 1682.

Halonen, P., Huebner, R. J., and Turner, H. C. (1958). Proceedings of the Society of Experimental Biology and Medicine, 97, 530.

Harnden, D. G., Elsdale, T. R., Young, D. E., and Ross, A. (1967). Blood, 30, 120.

Henle, G., and Henle, W. (1967). Cancer Research, 27, 2442.

Henson, D. (1967). Fournal of the American Medical Association, 199, 278. Horton, E. H. (1966). British Medical fournal, 1, 1419.

Jarousse, J., Grislain, J. R., Kerneis, J. P., and Bruneau, Y. (1956).

Presse Médicale, 64, 1592.
Kääriäinen, L., Paloheimo, J., Klemola, E., Mäkelä, T., and Koivuniemi, A. (1966a). Annales Medicinae Experimentalis et Biologiae Fenniae, 44, 297.

Kääriäinen, L., Klemola, E., and Paloheimo, J. (1966b). British Medical fournal, 1, 1270.

Kissling, R. E., and Addison, B. V. (1964). Fournal of the National Cancer Institute, 32, 981.

Klemola, E., and Kääriäinen, L. (1965). British Medical fournal, 2,

Krech, U., and Jung, M. (1968). Therapeutische Umschau und Medizin-

ische Bibliographie, 25, 182 . (1960). Surgery, Gymecology and Obstetrics, 111, 317.

Lamb, S. G., and Stern, H. (1966). Lancet, 2, 1003. Lang, D. J.; Scolnick, E. M., and Will

Langenhuysen, M. M., and Kapsenberg, J. G. (1968). Nederlandsch Tijdschrift voor Geneeskunde, 112, 2125

Marton, P. F., Ulstrup, J. C., and Haugen, H. F. (1968). Tidsskrift for den Norske Lageforening, 88, 389.

Moore, G. E., Gerner, R. E., and Franklin, H. A. (1967). Fournal of the American Medical Association, 199, 519.

Murphy, A. M., Arnold, B. J., Keogh, H. J., and Jack, I. (1967). Medical fournal of Australia, 1, 562 .

Nieder fournal of Australia, 1, W. Henle, G., and Henle, W. (1968), fournal of the American Medical Association, 203, 205.

Reyman, T. A. (1966). American Heart fourmal, 72, 116. Stulberg, C. S., Zuelzer, W. W., Page, R. H., Taylor, P. E., and Biology A. J. (1966). Proceedings
and Medicine, 123, 976.

Toghill, P. J., Bailey, M. E., Williams, R., Zeegen, R., and Bown, R (1967). Eancet, 1, 1351.

Vogel, F. S. (1958). American foumal of Pathology, 34, 1069. yatt, J. P., Hemsath, F. A., and Soash, M. D. (1951). Americar fournal of Clinical Pathology, 21, 50.

Zuelzer, W. W., Stulberg, C. S., Page, R. H., Teruya, J., and Brough A. J. (1966). Transfusion, 6, 438. 